\title{
CYTOTOXICITY OF INTERMAXILLARY ORTHODONTIC ELASTICS OF DIFFERENT COLORS: AN IN VITRO STUDY
}

\author{
Rogério Lacerda dos SANTOS ${ }^{1}$, Matheus Melo PITHON${ }^{1}$, Gabriella da Silva MENDES ${ }^{2}$, Maria Teresa Villela ROMANOS ${ }^{3}$, \\ Antônio Carlos de Oliveira RUELLAS ${ }^{4}$
}

\begin{abstract}
1- DDS, MSc, Specialist in Orthodontics, Federal University of Alfenas, Alfenas, MG, Brazil; Master in Orthodontics, Federal University of Rio de Janeiro, Rio de Janeiro, RJ, Brazil; PhD Student in Orthodontics, Federal University of Rio de Janeiro, Rio de Janeiro, RJ, Brazil.

2- DDS, MSc Graduate student in Microbiology, Federal University of Rio de Janeiro, Rio de Janeiro, RJ, Brazil.

3- DDS, MSc, PhD, Assistant Professor of Microbiology, Federal University of Rio de Janeiro, Rio de Janeiro, RJ, Brazil.

4- DDS, MSc, PhD, Invited Professor, Specialization Course in Orthodontics, School of Pharmacy and Dentistry of Alfenas, Alfenas, MG, Brazil; Adjunct Professor in Orthodontics, Federal University of Rio de Janeiro, Rio de Janeiro, RJ, Brazil.
\end{abstract}

Corresponding address: Dr. Rogério Lacerda dos Santos - Praça José Batista de Freitas, 78, 102 - centro -Nova Serrana - MG - Brazil - 35519-000 e-mail: lacerdaorto@hotmail.com

Received: July 21, 2008 - Modification: November 09, 2008 - Accepted: November 15, 2008

\begin{abstract}
$O$

bjectives: Natural latex does not fall into the category of materials known to be entirely inoffensive. The purpose of this in vitro study was to test the hypothesis that there is no difference in the cytotoxicity between elastics of different colors and those from different manufacturers. Material and Methods: Different latex intraoral elastics of different colors $(5 / 16=7.9 \mathrm{~mm}$, mean load) were compared. The sample was divided into 7 groups of 24 elastics each: Group T (TP Orthodontics, natural latex elastics, control); Groups U1, U2, U3, U4, U5 and U6 (Uniden, natural latex elastics and colored elastics, namely, green, pink, yellow, red and purple, respectively). Cytotoxicity assays were performed by using cell culture medium containing epithelioid-type cells (Hep-2 line) derived from human laryngeal carcinoma. The cytotoxicity was evaluated by using the "dye-uptake" test, which was employed at two different moments ( 0 and $24 \mathrm{~h}$ ). Data were compared by analysis of variance (ANOVA) and Tukey's test $(\mathrm{p}<0.05)$. Results: There was statistically significant difference $(\mathrm{p}<0.05)$ between Group T and all other groups (U1, U2, U3, U4, U5 and U6) at 0 and 24 h. No statistically significant difference $(\mathrm{p}<0.05)$ was found between Groups U1 and U5, U1 and U6, U2 and U3, U2 and U4, U2 and $\mathrm{U} 5, \mathrm{U} 2$ and $\mathrm{U} 6, \mathrm{U} 3$ and $\mathrm{U} 4, \mathrm{U} 3$ and U5, U3 and U6, U4 and U5, U4 and U6, and U5 and U6 at 0 and 24 h. Conclusions: The TP Orthodontics elastics promoted less cell lysis compared to the Uniden elastics regardless of their color.
\end{abstract}

Key words: Cytotoxicity. Elastics. Biocompatibility. Orthodontics.

\section{INTRODUCTION}

The biocompatibility of dental materials has been theme of great speculation and uncertainty. There are, particularly in Orthodontics, several materials keeping direct contact with organic tissues for long periods of time. Recent studies have been concerned with the biocompatibility of different types of orthodontic materials ${ }^{7,18}$.

Pre-vulcanized latex is produced by mixing pure natural latex, which has the highest molecular weight ${ }^{19}$, with stabilizers such as zinc oxide and chemically vulcanized materials. The resulting mixture is then heated until $70^{\circ} \mathrm{C}^{12}$. Although zinc is known to be neurotoxic ${ }^{8}$, the amount released by orthodontic elastics can be ingested as research studies show no evidence of harm ${ }^{6}$. Anti-ozone and antioxidant agents are also added to latex during the manufacture of orthodontic elastics ${ }^{19}$. This process has the advantage of producing latex with higher mechanical properties, thus increasing its strength and elasticity ${ }^{6,12}$. However, natural latex is not in the category of materials known to be entirely inoffensive $e^{4,14}$. Allergy caused by latex proteins has been well documented ${ }^{11}$, including immediate hypersensitivity reactions ${ }^{20}$. Amongst the allergic reactions caused by orthodontic elastics, swelling and stomatitits, erythematous oral lesions, respiratory reactions, and even anaphylactic shock, the most severe form of allergy ${ }^{2,16}$, can be cited. Latex allergy occurs in $3-17 \%$ of the cases ${ }^{17}$.

The use of cell culture medium for testing the toxicity of dental products is a valid way of understanding the biological behavior of such materials ${ }^{14}$. The objective of the present in vitro study was to test the hypothesis that there is no difference in the cytotoxicity between elastics of different colors and those from different manufacturers. 


\section{MATERIAL AND METHODS}

Intraoral latex elastics of different colors $(5 / 16 "=7.9$ $\mathrm{mm}$, mean load) were selected for studying their cytotoxicity on oral tissues (Table 1). The samples were divided into 7 groups of 24 elastics each according to their manufacturers: Group T (natural latex elastics, control; TP Orthodontics, Lodi, CA, USA), Groups U1, U2, U3, U4, U5 and U6 (natural latex elastics and colored elastics, namely, green, pink, yellow, red and purple, respectively; Uniden, Sorocaba, SP, Brazil). All elastics used in this study were obtained from the same production lot.

Dental copper amalgam (Vigodent, Rio de Janeiro, RJ, Brazil) with standard size and weight was used as positive control, whereas stainless steel orthodontic wire (American Orthodontics, Sheboygan, Wisconsin) was used as negative control (Table 1).

Cell culture containing Hep-2 line cells (human laryngeal carcinoma) was maintained in Eagles' minimum essential medium (MEM; Cultilab, Campinas, SP, Brazil) by adding $0.03 \mathrm{mg} / \mathrm{ml}$ of glutamine (Sigma, St. Louis, MO, USA), 50 $\mu \mathrm{g} / \mathrm{mL}$ of garamicine (Schering Plough, Kenilworth, NJ, USA), $2.5 \mathrm{mg} / \mathrm{mL}$ of fungizone (Bristol-Myers-Squibb, New York, NY, USA), $0.25 \%$ sodium bicarbonate solution (Merck, Darmstadt, Germany), $10 \mathrm{mM}$ of HEPES (Sigma), and $10 \%$ bovine fetal serum (Cultilab) for growth medium or no bovine fetal serum for maintenance medium only. Next, the cell culture medium was incubated at $37^{\circ} \mathrm{C}$ for $48 \mathrm{~h}$.

The elastics of experimental and control groups had their both sides previously sterilized with ultraviolet light (Labconco, Kansas, MO, USA) during $30 \mathrm{~min}$. The method for evaluating the cytotoxicity was the "dye-uptake" 10 assay. This method is based on neutral red dye incorporated into live cells. It was used in this experiment only at two periods of evaluation: 0 and $24 \mathrm{~h}$. The $0-\mathrm{h}$ period represents the contact and immediate removal of the elastic from cell culture medium, whereas the $24-\mathrm{h}$ period represents the maintenance of the elastic in the cell culture medium for 24 $\mathrm{h}$ after removal.

Aliquots of $100 \mu \mathrm{L}$ of Hep- 2 cells were distributed into 96-well microplates. After $48 \mathrm{~h}$, the growth medium was replaced with $100 \mu \mathrm{L}$ of MEM obtained following incubation in the different types of elastics at 0 and $24 \mathrm{~h}$.
Positive and control groups consisted of culture medium put in contact with amalgam and stainless steel wire, respectively. The experiment was repeated four times.

After $24-\mathrm{h}$ incubation, $100 \mu \mathrm{L}$ of $0.01 \%$ neutral red dye (Sigma) were added to the culture medium in the 96-well microplates, which were incubated again for $3 \mathrm{~h}$ at $37^{\circ} \mathrm{C}$ so that the red dye could penetrate the live cells. Following this period of time, $100 \mu \mathrm{L}$ of $4 \%$ formaldehyde solution (Vetec, Rio de Janeiro, RJ, Brazil) in PBS (130 mM of NaCl; $2 \mathrm{mM}$ of $\mathrm{KCl} ; 6 \mathrm{mM}$ of $\mathrm{Na}_{2} \mathrm{HPO}_{4} 2 \mathrm{H}_{2} \mathrm{O} ; 1 \mathrm{mM}$ of $\mathrm{K}_{2} \mathrm{HPO}_{4}$ $1 \mathrm{mM} ; \mathrm{pH} 7.2$ ) were added in order to promote cell attachment to the plate. After $5 \mathrm{~min}, 100 \mu \mathrm{L}$ of $1 \%$ acetic acid (Vetec) and 50\% methanol (Vetec) were added in order to remove the dye. After $20 \mathrm{~min}$, a spectrophotometer (BioTek, Winooski, VT, USA) at $492 \mathrm{~nm}$ wavelength $(\lambda=492$ $\mathrm{nm})$ was used for data reading.

Data were subjected to ANOVA and Tukey's multiplecomparison test was used for identifying differences between the groups. Significance level was set at $\mathrm{p}<0.05$.

\section{RESULTS}

The results showed statistically significant differences between Groups T (TP Orthodontics, natural latex) and U1 (Uniden, natural latex), T (TP Orthodontics, natural latex) and U2 (Uniden, green color), T (TP Orthodontics, natural latex) and U3 (Uniden, pink color), T (TP Orthodontics, natural latex) and U4 (Uniden, yellow color), T (TP Orthodontics, natural latex) and U5 (Uniden, red color) and T (TP Orthodontics, natural latex) and U6 (Uniden, purple color) ( $\mathrm{p}=0.00), \mathrm{U} 1$ and $\mathrm{U} 2(\mathrm{p}=0.003), \mathrm{U} 1$ and U3 (p $=0.015)$ and $\mathrm{U} 1$ and $\mathrm{U} 4(\mathrm{p}=0.005)$. No statistically significant difference was found between Groups U1 and U5 ( $p=0.796)$, U1 and U6 ( $p=0.992), \mathrm{U} 2$ and U3, U2 and $\mathrm{U} 4, \mathrm{U} 3$ and $\mathrm{U} 4, \mathrm{U} 5$ and $\mathrm{U} 6(\mathrm{p}=1.00), \mathrm{U} 2$ and $\mathrm{U} 5(\mathrm{p}=0.398)$, $\mathrm{U} 2$ and U6 ( $\mathrm{p}=0.091), \mathrm{U} 3$ and U5 $(\mathrm{p}=0.686), \mathrm{U} 3$ and U6 $(\mathrm{p}=0.242)$, U4 and U5 ( $\mathrm{p}=0.468)$, and $\mathrm{U} 4$ and $\mathrm{U} 6(\mathrm{p}=0.119)$ at $0 \mathrm{~h}$ (Table 2).

After immersing the elastics, the 24-h cytotoxicity assay showed similar results to those of 0 -h cytotoxicity using the dye-uptake method.

There were statistically significant differences $(p=0.00)$

TABLE 1- Experimental and control groups used for the assays

\begin{tabular}{lccc}
\hline Groups & Trademark & Color & Reference number \\
\hline T & TP Orthodontics & Natural & $360-012$ \\
U1 & Uniden & Natural & $000-1204$ \\
U2 & Uniden & Green & $000-1206$ \\
U3 & Uniden & Pink & $000-1206$ \\
U4 & Uniden & Yellow & $000-1206$ \\
U5 & Uniden & Red & $000-1206$ \\
U6 & Uniden & Purple & $000-1206$ \\
Positive Control & & Dental copper amalgam. Pratic NG 2. Vigodent & \\
Negative Control & Stainless steel wire. American Orthodontics. 0.019"x 0.025” \\
\hline
\end{tabular}


TABLE 2- Dye-uptake technique. Descriptive statistics for optical density

\begin{tabular}{|c|c|c|c|c|c|c|c|c|c|}
\hline \multirow[t]{3}{*}{ Groups } & \multirow[t]{3}{*}{$\mathbf{N}$} & \multicolumn{8}{|c|}{ Time } \\
\hline & & \multicolumn{4}{|c|}{$\mathbf{O h}$} & \multicolumn{4}{|c|}{$24 \mathrm{~h}$} \\
\hline & & Mean & Median & SD & $\begin{array}{c}\% \text { viable } \\
\text { cells }\end{array}$ & Mean & Median & SD & $\begin{array}{c}\% \text { viable } \\
\text { cells }\end{array}$ \\
\hline CC & 24 & $0.547^{a}$ & 0.57 & 0.062 & 100.0 & $0.648^{a}$ & 0.690 & 0.142 & 100.0 \\
\hline C- & 24 & 0.527 & 0.545 & 0.076 & 96.3 & 0.622 & 0.678 & 0.164 & 95.9 \\
\hline $\mathrm{C}+$ & 24 & 0.257 & 0.251 & 0.035 & 46.9 & 0.306 & 0.307 & 0.073 & 47.2 \\
\hline $\mathbf{T}$ & 24 & $0.526^{a}$ & 0.538 & 0.052 & 96.1 & $0.598^{a}$ & 0.696 & 0.234 & 92.2 \\
\hline U1 & 24 & $0.091^{b}$ & 0.089 & 0.006 & 16.6 & $0.115^{b}$ & 0.087 & 0.077 & 17.7 \\
\hline U2 & 24 & $0.048^{c}$ & 0.048 & 0.002 & 8.7 & $0.074^{\mathrm{cb}}$ & 0.074 & 0.007 & 11.4 \\
\hline U3 & 24 & $0.052^{\mathrm{dc}}$ & 0.05 & 0.007 & 9.5 & $0.080^{d b c}$ & 0.079 & 0.005 & 12.3 \\
\hline U4 & 24 & $0.049^{\text {ecd }}$ & 0.049 & 0.002 & 8.9 & $0.080^{\mathrm{ebcd}}$ & 0.078 & 0.005 & 12.3 \\
\hline U5 & 24 & $0.073^{\text {fbcde }}$ & 0.071 & 0.008 & 13.3 & $0.088^{\text {fbcde }}$ & 0.087 & 0.010 & 13.5 \\
\hline U6 & 24 & $0.080^{\text {gbfcde }}$ & 0.078 & 0.010 & 14.6 & $0.114^{\text {gbcdef }}$ & 0.106 & 0.024 & 17.5 \\
\hline
\end{tabular}

$\mathrm{N}=24$. Values followed by same letters are not significantly different $(p>0.05)$ for the same time point. SD: standard deviation.

between groups $\mathrm{T}$ and $\mathrm{U} 1, \mathrm{~T}$ and $\mathrm{U} 2, \mathrm{~T}$ and $\mathrm{U} 3$, $\mathrm{T}$ and $\mathrm{U} 4$, $\mathrm{T}$ and $\mathrm{U} 5$ and T and U6. On the other hand, no statistically significant difference was found between groups U1 and $\mathrm{U} 2$ ( $\mathrm{p}=0.760)$, U1 and U3 ( $\mathrm{p}=0.880), \mathrm{U} 1$ and $\mathrm{U} 4$ ( $\mathrm{p}$ $=0.878), \mathrm{U} 1$ and $\mathrm{U} 5(\mathrm{p}=0.978), \mathrm{U} 1$ and U6, U2 and U3, $\mathrm{U} 2$ and $\mathrm{U} 4, \mathrm{U} 2$ and $\mathrm{U} 5, \mathrm{U} 3$ and $\mathrm{U} 4, \mathrm{U} 3$ and $\mathrm{U} 5$ and $\mathrm{U} 4$ and $\mathrm{U} 5$ ( $\mathrm{p}=1.00), \mathrm{U} 2$ and $\mathrm{U} 6(\mathrm{p}=0.797), \mathrm{U} 3$ and $\mathrm{U} 6(\mathrm{p}=0.905)$, U4 and U6 (p =0.903) and U5 and U6 (p=0.985) in time the $24 \mathrm{hs}$ (Table 2).

\section{DISCUSSION}

In the present study, dental copper amalgam and stainless steel wire were used as positive and negative controls (Table 1), respectively, because they have been proven to be adequate for this type of assay ${ }^{9}$. Dental amalgam is potentially cytotoxic due to the presence of mercury, but there are also other neurotoxic substances depending on their composition and manufacturation ${ }^{8}$.

As sterilization is a prerequisite for cytotoxicity assay, ultraviolet light was used in the present study for sterilizing both sides of the elastics ${ }^{9}$ during $30 \mathrm{~min}$. All elastics were found to have the same color and malleability following UV light sterilization.

The percentage of viable cells was obtained by comparing the mean optical density (OD) of control cells (no contact with the materials) to that of cell cultures put in contact with different elastics, resulting in 50\% toxicity for the cell cultures $\left(\mathrm{CC}_{50}\right)$ (Table 2$)$.

In respect to in vitro experiments, three different methods can be employed: evaluation of chromium release, Millipore membrane filtration, and agar overlay test ${ }^{13}$. Increasingly more reliable procedures have been sought and new evaluation methods were proposed, such as the dye-uptake technique ${ }^{10}$ in which neutral red dye is incorporated by the cells through a rapid and objective assay, thus saving time and allowing evaluating the initial cytotoxic effect of dental materials.

According to Schmalz ${ }^{14}$, the major risk factor for using potentially cytotoxic intraoral elastics would be that substances being released from the elastics could be ingested by the patient over time, potentially causing diseases due to the toxic substance accumulation. It is known that latex is not entirely biocompatible as it may cause allergic reactions ${ }^{17,19}$ and interact with food ${ }^{1,17}$ and medications $s^{15}$. Nevertheless, the potential for hypersensitivity may not be related to the potential for cytotoxicity. In other words, the material may be allergenic but not cytotoxic, although the contrary may not be true.

As dental latex elastics are widely used in clinical orthodontics, the cytotoxic effects they may produce should be taken into account, particularly the intraoral elastics because of their continuous and prolonged contact with the mucosa. Therefore, biocompatible materials should be selected if such a concern occurs. Previous studies on the toxicity of orthodontic latex elastics have shown that they were toxic to gingival fibroblasts ${ }^{14}$.

A cytotoxic effect was demonstrated after exposing the elastics to the culture medium. The Uniden elastics were found to cause more cell death in comparison to TP Orthodontics elastics, suggesting the former are less biocompatible than the latter and supporting findings of Lacerda-Santos, et al. ${ }^{9}$ as well. Variations occur in the composition of the latex elastics and this could explain the different results between the two trademarks. Although in vitro experiments do not simulate the oral environment in all its aspects, elastics should not be considered clinically inert $^{9}$. It is important that the dentist knows how to manage patients presenting latex allergy and how to deal with this problem ${ }^{5}$. An alternative for patients with allergy to latex is to use latex-free elastics, which can be used in orthodontics without jeopardizing the orthodontic treatment ${ }^{3}$. 


\section{CONCLUSION}

It may be concluded that: 1 . TP Orthodontics intraoral elastics were found to cause low cell lysis; 2 . Uniden intraoral elastics were found to be highly cytotoxic, regardless of their color and contact time with the cell cultures.

\section{REFERENCES}

1- Carey AB, Cornish K, Schrank P, Ward B, Simon R. Cross-reactivity of alternate plant sources of latex in subjects with systemic IgE-mediated sensitivity to Hevea brasiliensis latex. Ann Allergy Asthma Immunol. 1995; 74:317-20.

2- Everett FG, Hice TL. Contact stomatitis resulting from the use of orthodontic rubber elastics: report of case. J Am Dent Assoc. 1974;88:1030-1.

3- Gandini P, Gennai R, Bertoncini C, Massironi S. Experimental evaluation of látex-free orthodontic elastics behaviour in dynamics. Prog Orthod. 2007;8:88-99.

4- Holmes J, Barker MK, Walley EK, Tuncay OC. Cytotoxicity of orthodontic elastics. Am J Orthod Dentofacial Orthop. 1993;104:188-91.

5- Hain MA, Longman LP, Field EA, Harrison JE. Natural rubber latex allergy: implications for the orthodontist. J Orthod. 2007;34:6-11

6- Hanson M, Lobner D. In vitro neuronal cytotoxicity of latex and nonlatex orthodontic elastics. Am J Orthod Dentofacial Orthop. 2004;126:65-70.

7- Kao CT, Ding SJ, He H, Chou MY, Huang TH. Cytotoxicity of orthodontic wire corroded in fluoride solution in vitro. Angle Orthod. 2007;77:349-54

8- Lobner D, Asrari M. Neurotoxicity of dental amalgam is mediated by zinc. J Dent Res. 2003;82:243-6.

9- Lacerda-Santos R, Pithon MM, Oliveira MV, Mendes GS, Romanos MTV, Ruellas ACO. Cytotoxicity of intraoral orthodontic elastics. Braz J Oral Sci. 2008;24:1520-5.

10- Neyndorff HC, Bartel DL, Tufaro F, Levy JG. Development of a model to demonstrate photosensitizer-mediated viral inactivation in blood. Transfusion. 1990;30:485-90.

11- Palosuo T, Alenius H, Turjanmaa K. Quantitation of latex allergens. Methods. 2002;27:52-8.

12- Perrella FW, Gaspari AA. Natural rubber latex protein reduction with an emphasis on enzyme treatment. Methods. 2002;27:77-86.

13- Stanford JW. Recomended standard practices for biological evaluation of dental materials. Int Dent J. 1980;30:140-88.

14- Schmalz G. Use of cell cultures for toxicity testing of dental materials: advantages and limitations. J Dent. 1994;22(Suppl 2):S6-11.

15- Towse A, O'Brien M, Twarog FJ, Braimon J, Moses AC. Local reaction secondary to insulin injection: a potential role for latex antigens in insulin vials and syringes. Diabetes Care. 1995;18:1195-7.

16- Tomazic VJ, Withrow TJ, Fisher BR, Dillard SF. Latex-associated allergies and anaphylactic reactions. Clin Immunol Immunopathol. 1992;64:89-97.

17- Turjanmaa K, Alenius H, Makinen-Kiljunen S, Reunala T, Palosuo T. Natural rubber latex allergy. Allergy. 1996;51:593-602.
18- Vande Vannet BM, Hanssens JL. Cytotoxicity of two bonding adhesives assessed by three-dimensional cell culture. Angle Orthod. 2007;77:716-22.

19- Weiss ME, Hirshman CA. Latex allergy. Can J Anaesth. 1992;39:52832.

20- Wakelin SH, White IR. Natural rubber latex allergy. Clin Exp Dermatol. $1999 ; 24: 245-8$. 